\title{
Tobacco and end stage renal disease: a multicenter, cross-sectional study in Argentinian Northern Patagonia
}

Maria M. Alba ${ }^{1,3^{*}}$, Alicia N. Citarelli ${ }^{1}$, Fernanda Menni ${ }^{2}$, Maria Agricola ${ }^{1}$, Alejandra Braicovich ${ }^{1}$, Eduardo De Horta ${ }^{1}$, Fernando De Rosa ${ }^{1}$, Graciela Filanino ${ }^{1}$, Raul Gaggiotti ${ }^{1}$, Nelson Junqueras ${ }^{1}$, Sandra Martinelli ${ }^{1}$, Adriana Milan ${ }^{1}$, Mabel E. Morales', Silvia Setti ${ }^{1}$ and Daniel O. Villalba ${ }^{3}$

\begin{abstract}
Background: Smoking and chronic kidney disease are major public health problems with common features -high prevalence and mortality, high cardiovascular risk, gender differences and high prevalence in low income people-, but the link between them is poorly recognized. Our objectives were to investigate the exposure of dialysis patients to tobacco and to know their smoking behavior.

Methods: We performed a multicenter, cross-sectional study in nine dialysis units in the Argentinian Northern Patagonia. We investigated smoker status, lifetime tobacco consumption, current tobacco use, breath carbon monoxide and \% carboxyhaemoglobin. Fagerström and Richmond tests were performed for active smokers. Statistical analysis: one way ANOVA and Tukey's test for post hoc test. For exploratory analysis, frequency tables through chi-square distribution and single correspondence analysis were performed.

Results: Six hundred thirty six patients (60.9\% males, $39.1 \%$ females) were interviewed. Almost $70 \%$ of them had had tobacco exposure. Excluding light smokers, the lifetime consumption was significantly different $(p=0.0052)$ between sexes (33.1 \pm 2.4 pack/years in males and 18.2 \pm 2.1 pack/years in females) The distribution of etiologies changed significantly $\left(X^{2} p<0.0001\right)$ with smoker status and the dose of tobacco smoking, with an increase in the diagnosis of nephrosclerosis in patients with high and very high lifetime consumption (from $16.1 \%$ in non-smokers to 28.2 and $27 \%$ respectively), and in passive smokers (from 16.1 to $27.3 \%$ ). The male preponderance of end-stage renal disease disappeared when only non-smokers were considered and grew with the increase in the lifetime consumption. Active smokers have small consumption, both low $\mathrm{CO}$ level and \% $\mathrm{COHb}$, low dependence and a good motivation to quit, but a high lifetime consumption.

Conclusions: Exposure of dialysis patients to tobacco is high and could be related to the progression to the final stage of the renal disease. It seems that tobacco renal damage is mostly hidden in the diagnosis of nephrosclerosis. The gender difference observed in these patients could also have a nexus with the men's higher tobacco exposure. Active smokers have a low current consumption but a high lifetime tobacco dose.
\end{abstract}

Keywords: Chronic kidney disease, Dialysis, Tobacco renal damage, Cardiovascular diseases

\footnotetext{
* Correspondence: mechalba@hotmail.com

${ }^{1}$ Northern Patagonia Association of Nephrology, Entre Ríos 651, Neuquén 8300, Argentina

${ }^{3}$ Unidad Renal Cipolletti, España 885, Cipolletti 8332 Río Negro, Argentina

Full list of author information is available at the end of the article
}

C Biomed Central

(C) 2015 Alba et al. Open Access This article is distributed under the terms of the Creative Commons Attribution 4.0 International License (http://creativecommons.org/licenses/by/4.0/), which permits unrestricted use, distribution, and reproduction in any medium, provided you give appropriate credit to the original author(s) and the source, provide a link to the Creative Commons license, and indicate if changes were made. The Creative Commons Public Domain Dedication waiver (http://creativecommons.org/publicdomain/zero/1.0/) applies to the data made available in this article, unless otherwise stated. 


\section{Resumen}

Introducción: Tabaquismo y enfermedad renal crónica son importantes problemas de salud pública que comparten: alta prevalencia, alta morbi-mortalidad, alto riesgo cardiovascular, diferencias de género y mayor prevalencia en personas de bajos ingresos. Sin embargo, el nexo entre ellas es poco reconocido. Objetivos: mensurar la carga tabáquica de los enfermos en diálisis y conocer su patrón de consumo.

Material y métodos: Participaron nueve unidades de diálisis de la Norpatagonia Argentina. Investigamos condición de fumador, carga tabáquica y, en fumadores activos, consumo actual, tests de Richmond y Fagerström, monóxido de carbono en aire espirado y \% de carboxihemoglobina. Análisis estadístico: ANOVA de una vía y test de Tukey para análisis post hoc. En el análisis exploratorio, utilizamos tablas de frecuencias a través de la distribución Ji cuadrado y análisis de correspondencia simple.

Resultados: Seiscientos treinta y seis pacientes (60.9 \% varones, $39.1 \%$ mujeres) fueron encuestados. Casi un $70 \%$ de ellos había estado expuesto al tabaco. Excluyendo los fumadores leves, la carga tabáquica (CT) fue $33 \pm 2.4$ paquetes/año en hombres y $18.2 \pm 2.1$ paquetes/año en mujeres $(p=0.0052)$. La distribución de las etiologías de ingreso a diálisis cambió significativamente $\left(x^{2} p<0.0001\right)$ según el estado de fumador y la $C T$, con aumento en el diagnóstico de nefroesclerosis en fumadores pasivos (de $16.1 \%$ en no fumadores a $27.3 \%$ ) y en pacientes con elevadas CT (de 15.2 y $16 \%$ en CT leve y media a 28.2 y $27 \%$ en CT alta y muy alta). La preponderancia masculina de la población desapareció en no fumadores y creció con el incremento en la CT $\left(x^{2} p<0.0001\right)$. Los fumadores activos tienen bajo consumo, bajo nivel de CO y carboxihemoglobina, baja dependencia y están bien motivados para dejar, pero tienen una elevada $\mathrm{CT}$.

Conclusiones: La alta CT de los enfermos en diálisis podría generar o contribuir a la progresión de la enfermedad renal crónica. El daño renal por tabaco se esconde principalmente en el diagnóstico de nefroesclerosis y se relaciona con la CT. La diferencia de género de estos pacientes podría relacionarse con su exposición al tabaco. Los fumadores activos tienen bajo consumo pero elevada $\mathrm{CT}$.

\section{Background}

Chronic kidney disease (CKD) is now a worldwide public health priority [1], not only for the increasing tendency but also for the high risk for cardiovascular(CV) complications related to renal function loss. CV disease is 10-20 times higher in end-stage renal disease (ESRD) patients and their most important cause of death [2]

Smoking is another major public health problem associated with $\mathrm{CV}$ and renal disease in the long term [3, 4]. However, around $15 \%$ of incident dialysis patients smoke and over $60 \%$ report previous tobacco use [5]. Smoking and CKD have common features: high prevalence [6,7], high mortality $[8,9]$ high cardiovascular risk $[10,11]$ gender differences $[12,13]$ and both of them are linked to poverty $[14,15]$.

However, the nexus between both diseases has been underestimated, neglected or poorly recognized in nephrologycal and tobacco fields. On the other hand, the continued growth of the ESRD population around the world has been related to the underrecognition of earlier stages of CKD and risk factors for their development [16] such as hypertension, diabetes, obesity and smoking [17].

Clearly, the demographics of dialysis population has changed dramatically since the start of chronic dialysis in three essential aspects: etiology, incident age and presence of comorbid conditions. In the seventies, chronic glomerulonephritis and pielonephritis were the two more frequent causes of entry to renal replacement therapy as shown in registries [18] of that time. In fact, both represented $75 \%$ of the total dialysis population and, surprisingly, the "microscopic renal vascular disease" (nephrosclerosis) represented only $3.5 \%$ of etiologies and "diabetic glomerulonephritis" appeared in the list of "rarer diseases". Back then, the majority of patients were 20-54 years old when treatment commenced. On the contrary, in the last years, the leading causes of ESRD are diabetes and nephrosclerosis, [19] the mean age increased about a decade [20] and comorbid conditions rose dramatically [21]. In Argentina, it is more and more frequent to see incident dialysis patients with several previous vascular interventions (by-pass surgery, stenting, angioplasty) or comorbid conditions directly related to the smoking status (kidney, urinary tract or lung carcinomas). Also, it is usual to see patients smoking outside of the dialysis units while they are waiting for the dialysis session to begin or the arrival of the transfer vehicle to return home.

When in 2011 we analyzed our first results about the prevalence of smoking in dialysis units of Northern Patagonia Association of Nephrology (Abstract XVII Argentinian Congress of Nephrology), we were surprised by the high number of patients $(75 \%)$ with some history of tobacco exposure. 
The purpose of this research work was to measure the exposure to tobacco of ESRD patients in Argentinian Northern Patagonia in March-April 2013 and to get to know their pattern of tobacco use.

\section{Methods}

A multicenter, cross-sectional study was conducted in March-April 2013 to assess the smoking history and habits of ESRD patients in Argentinian Northern Patagonia. The thirteen dialysis units in the "Comahue region" were invited to participate in the study but only nine responded. The survey consisted of a questionnaire in order to know smoking status, lifetime consumption, current tobacco use, motivation to stop, nicotine physical dependence and history of other addictions. The two principal investigators visited each dialysis unit and interviewed patients face to face during the hemodialysis session or during the monthly control in the case of peritoneal dialysis patients. Medical records were reviewed to obtain information about time on dialysis and the diagnosis of renal disease. All patients interviewed were briefly informed about the risks of smoking (focus on $\mathrm{CV}$, vascular access and transplant risk) at the end of each interview and were offered counseling to stop in the case of active smokers. Also, the workers of the centers were informed about risks and trained in how to stimulate patients to stop.

\section{Smoking status}

Participants were divided into four groups: nonsmokers (those who had never smoked or had smoked under 100 cigarettes in their life), past smokers (those who had smoked more than 100 cigarettes in their life and had stopped smoking at least one year before the study entry), current smokers (who smoked at the moment of interview and had smoked at least 100 cigarettes in their life) and passive smokers (people exposed to environmental tobacco for at least 10 years).

\section{Lifetime tobacco consumption (LTC)}

It was estimated in pack-years. Pack-years were calculated by dividing the mean number of cigarettes smoked a day by 20 and multiplying with the number of smoking years. The LTC was calculated in current and past smokers and considered light if $<5$ pack/year, moderate if 5-15 pack years, heavy if 16-25 pack-years and very heavy if > 25 pack-years.

\section{Current smokers}

The smokers' clinical history was performed for each active smoker including the Fargeström and Richmond tests as well as the determination of breath carbon monoxide in parts per million (ppm CO) with the $\mathrm{piCO}^{+}$Smokelyzer. Blood carboxyhaemoglobin in percentages (\% $\mathrm{COHb}$ ) was calculated with the formula CO ppm x 0.16 .

\section{Statistical analysis}

Data was analyzed with InfoStat/P v.2013 [22] Results are shown as mean \pm SEM for continuous variables, and number and percentages for categorical variables. Comparison between variables was carried out through one way ANOVA and the post hoc test used was Tukey's testing. In order to determine the relation between variables, frequency tables through chi-square distribution were carried out. Besides when a relation did exist, single correspondence analysis was performed. Significant level was considered p-values $<0.05$.

\section{Results}

\section{Baseline characteristics}

Six hundred thirty six patients $(60.9 \%$ males, $39.1 \%$ females) from nine dialysis units in Argentinian Northern Patagonia (Comahue region) were interviewed. This region includes two provinces, Río Negro and Neuquén, with $1,189,911$ inhabitants, according to the last population census in 2010 (INDEC) [23] In both provinces, in December 2012, there were 1,185 patients under renal replacement therapy according to the Argentinian Register of Chronic Dialysis [19]; therefore, our sample included more than half of this dialysis population.

These patients comprised $98 \%$ of the total available population (hospitalized patients or those who did not attend the dialysis session the day of the survey, did not take part in the study and only one patient refused to respond) Their mean age was $57.3 \pm 0.6$ years. The mean time on renal replacement treatment was $68.4 \pm 2.5$ months and the treatment modality was hemodialysis in 596 patients and peritoneal dialysis in 40 patients. The etiologies of endstage renal disease were: glomerulonephritis (GN) $18 \%$, nephrosclerosis (NS) $19.2 \%$, obstructive uropathy (OU) $6.1 \%$, diabetes (DBT) $22.5 \%$, unknown (UK) $22.6 \%$ and others (OT) $11.5 \%$.

\section{Smoking status (SS)}

There were 93 (14.6\%) current smokers and 543 (85.4\%) non- current smokers. In the last group, 269 (49.5\%) were never smokers, and 274 (50.5 \%) were former smokers. But in the group of never smokers there were 77 (28.6\%) passive smokers (past or present). Therefore, almost $70 \%$ of the population had had tobacco exposure.

\section{Lifetime tobacco consumption (LTC)}

It was calculated in current and past smokers and was very high (>25 pack/years) in $24.4 \%$, high (16-25 pack/years) in $10.2 \%$, moderate (5-15 pack/years) in $21.6 \%$ and light $(<5$ pack/years) in $43.7 \%$. Excluding light smokers, the mean LTC was $33.1 \pm 2.4$ pack/years in males and 18.2 \pm 2.1 pack/years in females $(p=0.0052)$. The distribution of etiologies varied significantly $\left(\chi^{2} p<0.0001\right)$ according to smoker status (Table 1) and LTC (Table 2). 
Table 1 Differences in etiology distribution according to smoker status

\begin{tabular}{|c|c|c|c|c|c|}
\hline \multirow{2}{*}{$\begin{array}{l}\text { End-stage renal } \\
\text { disease etiology }\end{array}$} & \multicolumn{4}{|l|}{ Smoker status } & \multirow{2}{*}{$\begin{array}{l}\text { Total } \\
\text { (number } \\
\text { and \%) }\end{array}$} \\
\hline & Current (\% and $95 \% \mathrm{Cl}$ ) & Never $(\%$ and $95 \% \mathrm{Cl}$ & Passive (\% and $95 \% \mathrm{Cl}$ & Former (\% and $95 \% \mathrm{Cl}$ & \\
\hline Diabetes & $14(6-21.9)$ & $24.5(20.6-28.3)$ & $22(21.7-22.4)$ & $24(19.7-28.5)$ & $143(22.5)$ \\
\hline Glomerulonenephritis & $28(18.8-37.1)$ & $18.2(17.9-18.5)$ & $13(9-16.9)$ & $16(10.5-21.6)$ & $115(18.1)$ \\
\hline Nephrosclerosis & $19.3(19.2-19.5)$ & $16.1(10.3-21.9)$ & $27.3(21-33.5)$ & $19(18.4-19.5)$ & $122(19.2)$ \\
\hline Unknown & $23.7(22.7-24.6)$ & $25.5(19.9-31)$ & $16.9(12.4-21.3)$ & $22(19.8-23.9)$ & $144(22.6)$ \\
\hline Obstructive uropathy & 0 & $5.7(4.9-6.5)$ & $5.2(4.4-5.9)$ & $8.8(1.5-15.9)$ & $39(6.1)$ \\
\hline Others & $15(11.7-18.3)$ & $10(6.8-12.9)$ & $15.6(12.4-18.7)$ & $10.2(6.7-13.6)$ & $73(11.5)$ \\
\hline Total (number and \%) & $93(14.6)$ & $192(30.2)$ & $77(12.1)$ & $274(43.1)$ & $636(100)$ \\
\hline
\end{tabular}

The change in etiology distribution achieved statistical significance $\left(x^{2}=82.34 ; p<0.0001\right)$, with an important increase (from $16.1 \%$ to $27.3 \%$ ) in nephrosclerosis in passive smokers (bold text)

The diagnosis of nephrosclerosis increased in all categories of smoker but passive smokers showed a more important increase (from $16.1 \%$ in non-smokers to $27.3 \%$ ). In smokers with high and very high LTC, the percentages grew from 15.2 and $16 \%$ in light and medium LTC to 28.2 and $27 \%$ respectively.

\section{Gender}

Sex distribution differs significantly $\left(\chi^{2} p<0.0001\right)$ according to SS (Table 3).

In never smokers it was $54.2 \%$ for women and $45.8 \%$ for men, whereas in current and former smokers we observed male preponderance (75\%). If we consider only current and former smokers with high and very high LTC, the percentage rose to $85 \%$. Instead, female preponderance was observed in passive smokers. We also made a simple correspondence analysis to observed associations between age, gender and smoker status. Active smokers were younger than former smokers. Male gender was associated to past smoker and age over 40 years whereas female gender was related to non-smoker and passive smoker.

\section{Current smokers}

$17.8 \%$ of males and $9.6 \%$ of females were smokers $(n=93)$. Their average age was $48.3 \pm 1.6$ years, of which $74.2 \%$ were males and $25.8 \%$ were females. Current tobacco use was $<10$ cigarettes/day in $68.8 \%$ of cases, between $11-20 \mathrm{cig} / \mathrm{d}$ in $15 \%$, more than $20 \mathrm{cig} / \mathrm{d}$ in $5.3 \%$ and there were another $10.8 \%$ of patients with recent quitting (less than one year) that we cannot yet consider former smokers. Only one patient consumed more than $31 \mathrm{cig} / \mathrm{d}$. LTC was very high in 35 smokers, high in eight, moderate in 25 and light in the other 25. According to Richmond test, $26.9 \%$ of patients were in the precontemplation stage, $39.8 \%$ in the contemplation stage and $22.5 \%$ in preparation phase (high motivation for quitting). According to Fagerström test, dependence was low in $90.3 \%$. Other addictions were informed in 24 cases (alcohol, analgesic or illegal drugs). Average level of breath $\mathrm{CO}$ was $10.8 \pm 0.8 \mathrm{ppm}$ and $\% \mathrm{COHb} 1.7 \pm 0.1$.

\section{Discussion}

According to our investigation, it seems that dialysis units are nowadays bastions of heavy smokers (past or

Table 2 Etiologies and lifetime tobacco consumption in past and current smokers

\begin{tabular}{|c|c|c|c|c|c|}
\hline \multirow{2}{*}{$\begin{array}{l}\text { Etiology of end-stage } \\
\text { renal disease }\end{array}$} & \multicolumn{4}{|c|}{ Lifetime tobacco consumption (\% and $95 \% \mathrm{Cl}$ ) } & \multirow{2}{*}{$\begin{array}{l}\text { Total } \\
\text { (number } \\
\text { and \%) }\end{array}$} \\
\hline & Light $<5$ pack/years & Medium 5-15 pack/years & High 16-25 pack/years & Very high $>25$ pack/years & \\
\hline Diabetes & $19.6(16.6-22.6)$ & $24.7(22.1-27.2)$ & $15.4(13-17.8)$ & $24.7(21.9-27.6)$ & $79(21.5)$ \\
\hline Glomerulonephritis & $23.4(16.5-30.2)$ & $19.8(19.2-20.3)$ & $12.8(10.4-15.3)$ & $13.5(8.5-18.5)$ & $70(19.1)$ \\
\hline Nephrosclerosis & $15.2(8.2-22.2$ & $16(13.2-18.9)$ & $28.2(24.9-31.6)$ & $27(20.4-33.5)$ & $72(19.6)$ \\
\hline Unknown & $23.4(20.8-26)$ & $19.8(18.1-21.4)$ & $28.2(25.7-30.7)$ & $18(14.6-21.4)$ & $80(21.8)$ \\
\hline Obstructiveuropathy & $6.3(5.6-7)$ & $3.7(1.2-6.2)$ & $2.6(0.9-4.2)$ & $12.4(7.4-17.3)$ & $25(6.8)$ \\
\hline Others & $12(10.7-13.4)$ & $16(12.1-20)$ & $12.8(12.2-13.5)$ & $4.5(1.45-10.4)$ & $41(11.2)$ \\
\hline Total (number and \%) & $158(43)$ & $81(22)$ & $39(11)$ & $89(24)$ & $367(100)$ \\
\hline
\end{tabular}

Lifetime tobacco consumption (LTC) was calculated in pack-years. The change observed in etiology distribution achieved statistical significance $\left(x^{2}=42.23 ; p<\right.$ 0.0001). The diagnosis of nephrosclerosis increased from $15.2 \%$ and $16 \%$ in patients with light and medium LTC to $28.2 \%$ and $27 \%$ in patients with high and very high LTC (bold text) 
Table 3 Gender and smoking status

\begin{tabular}{|c|c|c|c|c|}
\hline \multirow[t]{2}{*}{ Gender } & \multirow{2}{*}{$\begin{array}{l}\text { Current } \\
\text { smokers (\% and } \\
95 \% \mathrm{Cl})\end{array}$} & \multicolumn{3}{|c|}{ Current non smokers (\% and $95 \% \mathrm{Cl}$ ) } \\
\hline & & Never & Passives & Former \\
\hline Men (number $=387$ ) & $74.2(61.2-86.6)$ & $45.8(45.8-74.6)$ & $29.9(6-53.7)$ & $75.5(35.3-115.8)$ \\
\hline Women (number $=249$ ) & $25.8(13.4-38.2)$ & $54.2(54.2-83)$ & $70.1(46.3-94)$ & $24.5(15.8-64.7)$ \\
\hline All (number =636) & 93 & 192 & 77 & 274 \\
\hline
\end{tabular}

Sex distribution differed significantly $\left(x^{2} 81.84 ; p<0.0001\right)$ according to smoking status. The male preponderance of ESRD disappeared when we considered only never smokers and grew if we focused on former and current smokers; in passive smokers there was prominent female majority (bold text)

current) surviving thanks to modern medical advances. They have a low current consumption but an important lifetime consumption which might have influenced the progression to ESRD and could contribute to the gender difference observed in this disease. Also the exposure to second hand smoke could have a nexus with chronic kidney disease.

The suspicion that smoking could be a kidney risk factor dates back to the first half of the 20th century [24] but it took many years for the evidence supporting this suspicion to make itself present. Smoking was pointed out for the first time as a renal risk factor 35 years ago (1978) when Christiansen [25] reported a more rapid progress of diabetes nephropathy in smokers, and Dales [26] observed that the presence of proteinuria was more common in smokers and more prominent in heavy smokers. In the final years of the 20th century, prestigious nephrologists [27] highlighted something that cardiologists, neurologists and vascular surgeons had concluded many years earlier: that smoking was a vascular risk factor and, as a consequence, an important renal risk factor such as diabetes or hypertension which, basically, induce renal damage by means of vascular damage. However, for reasons difficult to understand, nephrologists couldn't accept something that seemed obvious if we consider that the vascular renal network is one of the widest of the body [28]. Perhaps, the reason for this omission is related to the silent characteristics of renal disease: there isn't "renal angina", the "vascular renal accident" is diagnosed only exceptionally, and the loss of renal function does not generate dramatic situations such as a myocardial infarction, a cerebral vascular accident, a member amputation or sexual disfunction. On the other hand, the delayed nephrology consultation leads to a significant number of patients starting renal replacement therapy without accurate diagnosis.

The tobacco exposure of our patients was similar to that reported by Banas et al. [29] in patients on the waiting list for renal transplant (70 \% of patients with tobacco exposure). This observation confirms our suspicion that there is more tobacco exposure in dialysis patients than in the general population, where the exposure reaches $50 \%$ [30] In that survey, the percentage of current smokers was higher $(24 \%)$ than in our investigation (14.6\%). Perhaps, this difference is a result of the fact that patients on the waiting list are younger, with less comorbidities, and are healthy enough to be able to smoke. Our prevalence of passive smokers was higher $(28.6 \%)$ than what was reported on the general population (12\%) [31] but very similar to what was reported in patients with coronary heart disease [32]. Unfortunately, in the Banas study, there was not information about these smokers.

The mean LTC found in our patients was higher than that reported by Banas (33.1 pack-years for men and 18.2 pack-years for women vs 17 and 14.5 pack-years respectively), but our analysis excluded smokers with $<5$ packyears and this could be the reason for the difference. Moreover, our study included all dialysis patients and the Banas study included only waiting list patients.

The etiologies of ESRD were comparable with those reported by the ARCD. Three etiologies, diabetes (23\%), nephrosclerosis (19\%) and unknown (23\%) lead the register including $65 \%$ of prevalent dialysis patients. However, when we focus on passive smokers and smokers with high and very high LTC, there is an important increase in the diagnosis of NS, suggesting that in this diagnosis the heaviest tobacco burden is hidden. In a survey on Swedish population, Ejerblad et al. [33] informed about the increase in the diagnosis of NS with the increase in LTC. We want to highlight the change observed in passive smokers because this feature is very important if we consider the reported relationship between passive smokers and vascular damage [34, 35]. Vascular, interstitial and glomerular lesions has been described in long-term smokers but vascular damage is preponderant [36, 37]. Cigarette smoke damages endothelial cells and nicotine induces smooth muscle cell proliferation [38]. Our study is the first to inform about the exposure to second hand smoke in ESRD patients.

The incidence and prevalence of ESRD is greater in men than in women [39] but the underlying mechanisms are not clearly identified. The factors involved may include diet, glomerular and kidney size, differences in glomerular hemodynamics or sex hormonal effects [40]. When we analyzed only never-smoking patients, the male preponderance disappeared, but it grew when we focused on smokers (past and current), and grew even more with the increase in tobacco exposure. When we looked at the 2012 ARCD [19], we were surprised by the fact that there 
are no gender differences until the age of 45 , but in the subsequent decades, the gender difference becomes increasingly prominent. This leads us to think that the difference may be caused by a factor that takes a long time to cause damage (tobacco?). Up to now there is not any survey that has investigated the role of tobacco in the greater prevalence of CKD on men, thus opening an interesting research field.

Finally, current smokers were about a decade younger than the total population with a relevant male preponderance $(74.2 \%$ men). In most of them, the actual consumption was low but LTC ( $>5$ pack-years in $70 \%$ ) was high. However, it has been reported that many persons quit smoking only after the onset of severe illness [41] Indeed, $10.8 \%$ of our patients had quit recently as a consequence of the impact of starting dialysis, as was pointed out by Banas et al. These patients gave us an excellent opportunity to encourage quitting, focusing on the specific benefits to quit [42] -lower obstruction rate of vascular access [43], lower cardiovascular risk [44] and better post- transplant evolution [45].

The Richmond test [46] was designed to know the readiness of the smoker to stop smoking. Prochaska and Di Clemente [47] developed the "stage of change model" for assessing it. About $40 \%$ of smokers in the general population are not ready to quit and another $40 \%$ are "unsure". Only $20 \%$ of smokers are ready to stop. In the case of our patients, if we add $22.5 \%$ of patients ready to stop to $10.8 \%$ of patients with recent quitting, we have $33.3 \%$ of patients with a good motivation to stop, which outnumbers the reported percentages of these change steps in the general population [48].

The Fagerström test [49] evaluates tobacco physical dependence. When physical dependence is high, consumption is also high and heavy smokers start to smoke early in the morning in order to increase their falling nicotine levels after night deprivation. Instead, smokers with ESRD have a small consumption that usually starts after midday and is influenced by the dialysis treatment: smokers with ESRD smoke before the dialysis treatment to relax and start smoking again very soon after the dialysis treatment. If we consider that these patients have smoked for many years and most of them have just had complications related to tobacco, it seems difficult to believe that they have "low dependence". We think that our patients may have tobacco psychological dependence that unfortunately we have not investigated, and maybe, the Fagerström test might require some changes for these particular patients.

Breath carbon monoxide is a risk marker for the development of diseases related to tobacco and a valid indirect marker of carboxyhaemoglobin level, with a linear relationship between them [50]. The mean level of carbon monoxide of our patients $(10.8 \mathrm{ppm})$ was a little over the cutoff point of $8 \mathrm{ppm}$ between smokers and non-smokers
[51] according to the low consumption reported by the majority of them. We observed a similar feature in the percentage of carboxyhaemoglobin $(1.7 \%)$ which has a cutoff point of $1.66 \%$ according to Jarzon et al. [52] However, these levels could be dangerous in the context of ESRD patients, frequently anaemic, with an extremely high cardiovascular risk.

Some smokers, such as smokers with COPD [53] have specials patterns of tobacco consumption (higher consumption, higher dependence and higher $\mathrm{CO}$ in exhaled air). Instead, our dialysis patients have a small current consumption, a low level of $\mathrm{CO}$, low dependence but an important LTC. Up to now, there has been no information about the smoking habits of ESRD patients and our study is the first to explore them.

The personal contact between patients and the two main investigators (especially trained in tobacco control) is the greatest strength of our study. On the contrary, the main limitations lie in the absence of a non-renal control population, the limited sample size and the presence in CKD patients of many confounding factors. Unfortunately, we were not able to demonstrate associations between LTC and non- renal complications linked to tobacco use because not all patients had been screened in the same way (it was a multicenter, cross-sectional study). However, if we add the present results to the cumulative evidence since the start of this century, it seems absolutely necessary to enlarge this cohort in order to achieve major statistical power.

\section{Conclusions}

The high exposure of dialysis patients to tobacco (past, passive or current) could be related to the increasing worldwide tendency of end stage renal disease and to the gender difference observed in this disease. The diagnosis of nephrosclerosis seems to hide the most important tobacco burden. Active smokers have low dependence, good motivation to quit, low actual consumption but high lifetime tobacco consumption. Nephrologists and tobacco specialists should work together to find a marker of "tobacco nephropathy" that permits their inclusion as an etiologic cause of ESRD.

\section{Competing interests}

The authors declared that they have no competing interests.

\section{Authors' contributions}

All the authors took part in the design of the investigation and in data interpretation. MMA and ANC visited each dialysis center for the interview of patients and FM performed the statistical analysis. All authors read and approved the final manuscript.

\section{Acknowledgments}

The authors would like to thank Pablo U. Massari MD for critical revision of manuscript and Gustavo E. Zabert MD and Global Bridges for tobacco training of members of Northern Patagonia Association of Nephrology. We also thank staff and patients of the dialysis units for their assistance during the survey and Raffo Laboratories for lending the piCO+ Smokelyzer. 
Received: 23 August 2014 Accepted: 20 August 2015

\section{Published online: 01 September 2015}

\section{References}

1. Couser W, Remuzzi G, Mendis S, Tonelli M. The contribution of chronic kidney disease to the global burden of major noncommunicable diseases. Kidney Int. 2011;80(12):1258-70. doi:10.1038/ki.2011.368.

2. Stack A, Bloembergen W. Prevalence and clinical correlates of coronary artery disease among new dialysis patients in the United States: a crosssectional study. J Am Soc Nephrol. 2001;12:1516-23.

3. Orth SR, Hallan SI. Smoking: a risk factor for progression of chronic kidney disease and for cardiovascular morbidity and mortality in renal patients-absence of evidence or evidence of absence? Clin J Am Soc Nephrol. 2008;3(1):226-36. doi:10.2215/CJN.03740907.

4. Schrier R. Smoking: the most preventable disease. Nat Clin Pract Nephrol. 2007;3(7):351.

5. Stack A, Murthy B. Cigarette use and cardiovascular risk in chronic kidney disease: an unappreciated modifiable lifestyle risk factor. Semin Dial. 2010;23(3):298-305.

6. Eriksen M, Mackay J, Ross H. The tobacco Atlas (4th ed): American Cancer Society and World lung Foundation. 2012.

7. US Renal data System UADR. Atlas of Chronic Kidney Disease and End-Stage Renal disease in the United States National Institutes of Health, National Institute of Diabetes and Digestive and Kidney disease; Bethesda MD

8. Carter BD, Abnet CC, Feskanich D, Freedman ND, Hartge P, Lewis CE, et al. Smoking and mortality-beyond established causes. N Engl J Med. 2015;372(7):631-40.

9. Rhee CM, Kovesdy CP. Epidemiology: Spotlight on CKD deaths-increasing mortality worldwide. Nat Rev Nephrol. 2015;11(4):199-200. doi:10.1038/ nrneph.2015.25.

10. White WB. Smoking-related morbidity and mortality in the cardiovascular setting. Prev Cardiol. 2007;10(2 Suppl 1):1-4.

11. Shlipak M, Fried L, Cushman M, Manolio T, Peterson D, Stehman-Breen C, et al. Cardiovascular mortality risk in chronic kidney disease: comparison of traditional and novel risk factors. JAMA. 2005;293(14):1737-45.

12. $\mathrm{Ng} \mathrm{M}$, Freeman MK, Fleming TD, Robinson M, Dwyer-Lindgren $L$, Thomson $\mathrm{B}$, et al. Smoking prevalence and cigarette consumption in 187 countries, 1980-2012. Jama. 2014;311(2):183-92. doi:10.1001/jama.2013.284692.

13. Eriksen $\mathrm{BO}$, Ingebretsen OC. The progression of chronic kidney disease: a 10-year population-based study of the effects of gender and age. Kidney Int. 2006;69(2):375-82. doi:10.1038/sj.ki.5000058.

14. Mackenbach J, Stirbu I, Roskam A, Schaap M, Menvielle G, Leinsalu M, et al. Socioeconomic inequalities in health in 22 European countries. N Engl J Med. 2008;358(23):2468-81.

15. Garcia-Garcia G, Jha V, Committee. WKDS. CKD in disadvantaged populations. Kidney Int. 2015;87(2):251-3.

16. Obrador GT, Pereira BJ, Kausz AT. Chronic kidney disease in the United States: an underrecognized problem. Semin Nephrol. 2002;22(6):441-8.

17. Hallan S, de Mutsert R, Carlsen S, Dekker FW, Aasarød K, Holmen J. Obesity, smoking and physical inactivity as risk factors for CKD: Are men more vulnerable? Am J Kidney Dis. 2006;47(3):396-405

18. Gurland HJ, Brunner FP, von Dehn H, Härlen H, Parsons FM, Schärer K. Combined report on regular dialysis and transplantation in Europe. Proc Europ Dialysis Transplant Assoc. 1973;10:17-57.

19. Marinovich S, Lavorato C, Bisigniano L, Soratti C, Hansen Krogh D, Celia E et al. Registro argentino de Diálisis Crónica 2011-Informe 2012 (Parte I). Nefrología Argentina. 2013;11(2).

20. Jager KJ, van Dijk PCW, Dekker FW, Stengel B, Simpson K, Briggs JD. The epidemic of aging in renal replacement therapy: an update on elderly patients and their outcomes. Clin Nephrol. 2003;60(5):352-60.

21. Bradbury BD, Fissell RB, Albert JM, Anthony MS, Critchlow CW, Pisoni RL, et al. Predictors of early mortality among incident US Hemodialysis patients in the dialysis outcomes and practise patterns study (DOPPS). Cl J Am Soc Nephrol. 2007;2(1):89-99.

22. Di Rienzo JA, Casanoves F, Balzarini MG, Gonzalez L, Tablada M, Robledo CW. Software estadístico. InfoStat versión 2013. Grupo InfoStat, FCA, Universidad Nacional de Córdoba, Argentina. 2013.

23. INDEC. Censo Nacional de Población, Hogares y Viviendas 2010. Argentina: Censo del Bicentenario; 2012.

24. Burn JH, Truelove LH, Burn I. The antidiuretic action of nicotine and of smoke. Br Med J. 1945;1:403-6.
25. Christiansen JS. Cigarette smoking and prevalence of microangiopathy in juvenile-onset insulin-dependent diabetes mellitus. Diabetes Care. 1978;1(3):146-9.

26. Dales LG, Friedman GD, Siegelaub AB, Seltzer CC, Ury HK. Cigarette smoking habits and urine characteristics: urinalysis abnormalities are more common is smokers, but the reasons are unclear. Nephron. 1978;20(3):167-70.

27. Orth SR, Ritz E, Schrier RW. The renal risks of smoking. Kidney Int. 1997;51(6):1669-77.

28. Aird WC. Phenotypic heterogeneity of the endothelium: II. Representative vascular beds. Circ Res. 2007;100(2):174-90. doi:10.1161/01.RES.0000255690. 03436.ae.

29. Banas MC, Banas B, Wolf J, Hoffmann U, Krüger B, Böger CA, et al. Smoking behaviour of patients before and after renal transplantation. Nephrol Dial Transplant. 2008;23(4):1442-6.

30. Pascual Lledó JF. Epidemiología del tabaquismo y morbimortalidad asociada con el consumo de tabaco en el mundo. In: Jiménez Ruiz CA FK, editor. Tratado de tabaquismo. Sweden: Aula Médica; 2011. p. 33-54.

31. Clemente Jiménez ML, Pau Pubil M, Pérez Trullén A, Trenc Español P, Rubio AE. Tabaquismo pasivo. In: Jiménez-Ruiz C, Fagerström K, editors. Tratado de tabaquismo. Madrid: Aula médica; 2011. p. 261-76.

32. Prugger CWJ, Heidrich J, De Bacquer D, Perier MC, Empana JP, Reiner Ž, et al. Passive smoking and smoking cessation among patients with coronary heart disease across Europe: results from the EUROASPIRE III survey. Eur Heart J. 2014;35(9):590-8.

33. Ejerblad E, Fored CM, Lindblad P, Fryzek J, Dickman PW, Elinder CG, et al. Association between smoking and chronic renal failure in a nationwide population-based case-control study. J Am Soc Nephrol. 2004;15:2178-85.

34. He J, Vupputuri S, Allen K, M.R. P, Hughes J, Whelton PK. Passive smoking and the risk of coronary heart disease. A metaanalysis of the epidemiologic studies. N Engl J Med. 1999;25(340):920-6.

35. Howard G, Burke GL, Szklo M, Tell GS, Eckfeldt J, Evans G, et al. Active and passive smoking are associated with increased carotid wall thickness. The Atherosclerosis Risk in Communities Study. Arch Intern Med. 1994;154(11):1277-82.

36. Lhotta K, Rumpelt HJ, Konig P, Mayer G, Kronenberg F. Cigarette smoking and vascular pathology in renal biopsies. Kidney Int. 2002;61(2):648-54. doi:10.1046/j.1523-1755.2002.00171.x.

37. Odoni G, Ogata H, Viedt C, Amann K, Ritz E, Orth SR. Cigarette smoke condensate aggravates renal injury in the renal ablation model. Kidney Int. 2002;61(6):2090-8. doi:10.1046/j.1523-1755.2002.00382.x.

38. Egleton RD, Brown KC, Dasgupta P. Angiogenic activity of nicotinic acetylcholine receptors: implications in tobacco-related vascular diseases. Pharmacol Ther. 2009;121(2):205-23. doi:10.1016/j.pharmthera.2008.10.007.

39. Silbiger $S R$, Neugarten J. The impact of gender on the progression of chronic renal disease. Am J Kidney Dis. 1995;25(4):515-33.

40. Silbiger $S$, Neugarten J. Gender and human chronic renal disease. Gend Med. 2008;5 Suppl A(Suppl A):S3-10. doi:10.1016/j.genm.2008.03.002.

41. Bak S, Sindrup SH, Alslev T, Kristensen O, Christensen K, Gaist D. Cessation of smoking after first-ever stroke: a follow-up study. Stroke. 2002;33(9):2263-9.

42. Orth SR. Cigarette smoking: an important renal risk factor - far beyond carcinogenesis. Tob Induc Dis. 2002;1(2):137-55. doi:10.1186/1617-9625-1-2-137.

43. Wetzig GA, Gough IR, Furnival CM. One hundred cases of arteriovenous fistula for haemodialysis access: the effect of cigarette smoking on patency. Aust N Z J Surg. 1985;55(6):551-4.

44. Foley RN, Herzog CA, Collins AJ. Smoking and cardiovascular outcomes in dialysis patients: the United States Renal Data System Wave 2 study. Kidney Int. 2003;63(4):1462-7. doi:10.1046/j.1523-1755.2003.00860.x.

45. Sung RS, Althoen M, Howell TA, Ojo AO, Merion RM. Excess risk of renal allograft loss associated with cigarette smoking. Transplantation. 2001;71(12):1752-7.

46. Richmond R. Teaching medical students about tobacco. Thorax. 1999;54(1):70-8.

47. Prochaska J, Di Clemente C. Treating addictive behaviors: process of change. New York: Plenum Press; 1986.

48. Ramos Pinedo A, Prieto GE. Estudio clínico del fumador. In: Jiménez-Ruiz CA, Fagerström KO, editors. Tratado de tabaquismo. Madrid: Aula médica; 2011. p. 295-308.

49. Fagerstrom KO, Schneider NG. Measuring nicotine dependence: a review of the Fagerstrom Tolerance Questionnaire. J Behav Med. 1989;12(2):159-82.

50. Pérez Trullén A, Lázaro Sierra J, Clemente Jiménez M, Herrero Labarga I, Pau Pubil M, Cascán HM. Marcadores biológicos y funcionales de susceptibilidad, exposición y lesión por el consumo de tabaco. In: Jiménez-Ruiz CA, Fagerström KO, editors. Tratado de tabaquismo. Madrid: Aula Médica; 2011. p. 323-40. 
51. Clark KD, Wardrobe-Wong N, Elliott JJ, Gill PT, Tait NP, Snashall PD. Cigarette smoke inhalation and lung damage in smokers volunteers. Eur Respir $\mathrm{J}$. 1998;12(2):395-9.

52. Janzon L, Lindell SE, Trell E, Larme P. Smoking habits and carboxyhaemoglobin: a cross-sectional study of an urban population of middleaged men. J Epidemiol Community Health. 1981;35:271-3.

53. Jiménez-Ruiz CA, Masa F, Miravitlles M, Gabriel R, Viejo J, Villasante C, et al. Smoking characteristics: differences in attitudes and dependence between healthy smokers and smokers with COPD. Chest. 2001;119(5):1365-70.

\section{Submit your next manuscript to BioMed Central} and take full advantage of:

- Convenient online submission

- Thorough peer review

- No space constraints or color figure charges

- Immediate publication on acceptance

- Inclusion in PubMed, CAS, Scopus and Google Scholar

- Research which is freely available for redistribution 